\title{
Victor McKusick, 1921-2008: the founder of medical genetics as we know it
}

\author{
European Journal of Human Genetics (2008) 16, 1161-1163; doi:10.1038/ejhg.2008.166
}

On the evening of 22 July 2008 Victor A. McKusick, born in Parkman, Maine on 21 October 1921, quietly passed away in his home in Towson, Maryland. On that same day he had been following the webcasting from Bar Harbor of the morning session of the 49th course in Medical Genetics where the special proclamation issued in his honour a few days earlier by the legislature of the State of Maine was read in front of faculty and students. His wife Dr Anne McKusick was at his side, as usual. Victor had prepared his own memorial, which took place at the Second Presbyterian Church in Baltimore on first of August 2008, with his meticulous style and with a touch of his well-known sense of humour. Two American colleagues, Clair Francomano and David Rimoin, had been invited by Victor himself like all the other speakers of the ceremony, to deliver his eulogy. While David spoke about 'The establishment of Medical Genetics' focusing on the number of scholarly achievements that characterized Victor's academic life, Clair described Victor as a 'Teacher, Mentor and Role Model' with a lot of touching and witty memories. Among these, Clair recalled that in one of their last conversations, when asked a question regarding his beliefs about afterlife Victor would answer: 'I am keeping an open mind about it...', Victor had a very profound personal sense of religion without ever showing it in public. His family, includes two pastors, his son Victor jr and his niece the Rev Barbara McKusick Liscord, the daughter of his twin brother Vincent. The story of his personal life, starting from his childhood, which he spent in his parents' farm in Maine, is as interesting in itself as a novel. He summarized it in an enticing way in the doctoral lecture he delivered on the occasion of the honorary degree in Medical Biotechnologies awarded to him and to Mario Capecchi on 12 May 2007 by the University of Bologna (it was, I believe his 24 th honorary degree). That lecture is part of the 'Homage to Victor A. McKusick' prepared for that occasion by the students and faculty of the European School of Genetic Medicine and is accessible through www.eurogene.org. While Mario Capecchi won the Nobel prize a few months later, Victor was conferred by the Emperor of Japan the prestigious Japan prize last April, 3 months before his death. It was a memorable occasion for Victor, which he joyfully partook together with his family and a few Hopkins colleagues as documented by the video you can find at www.japanprize.jp.

Victor was a living legend both at Johns Hopkins Hospital where he spent all his professional life, starting as a medical student in 1943, and all over the world. His presence on the international scene of modern Medical Genetics has been so prominent (from the launching of the 1st Birth Defects Conference to the organization of the Human Gene Mapping conferences together with Frank Ruddle and to the foundation of HUGO - Human Genome Organization) and his scientific achievements have been so numerous that I will have to concentrate only on his links with Europe using many personal memories arising from the courses of the European School of Genetic Medicine. He founded the School in 1988 in collaboration with many European medical geneticists who were to become the leaders of the newly reorganized European Society of Human Genetics a few years later (in 1990). The idea of the School goes back to 40 years ago when I, like many other young European geneticists of the time, got the opportunity to meet Victor personally at one of the Bar Harbor courses. In my case this happened in 1968, when I was a post-doc at Hopkins in the Department of Pediatrics, and I remember among the other European participants Albert de la Chapelle and the late Giorgio Filippi. The appeal of this course on young medical geneticists was enormous and 20 years later, in 1988, Victor helped us to establish a parallel course in Sestri Levante, Italy, thus initiating the long tradition of the School. The first course in Medical Genetics was a great success and for many of us (including Victor) was a sort of 'love at first sight' for the venue, for the students coming from all over Europe and for the idea itself of a 'Bar Harbor twin course'. Victor was considered the grandfather of the almost 100 students and the father of the 20 faculty. The course has been repeated every year since. Victor would always be sitting in the first row with many other faculty and moderating all the discussions. The tradition of the School required that faculty stay in residence and attend all lectures so that, as Victor was saying, 'they will keep each other honest' meaning that the quality of lectures is very much 


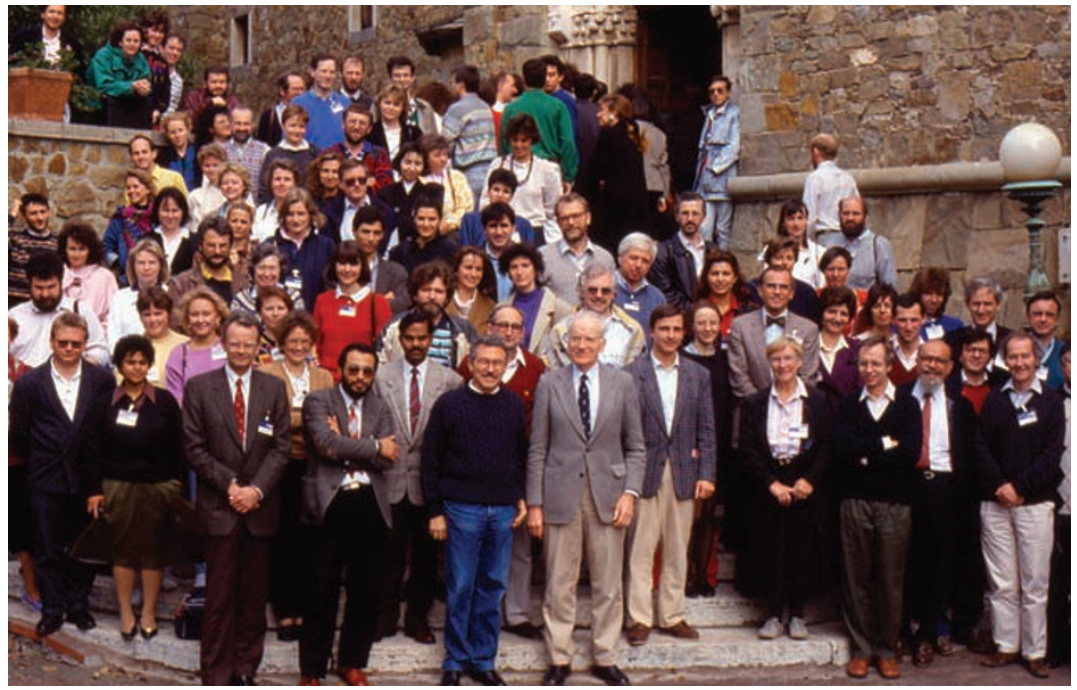

Figure 1 Faculty and students of the 7th course in Medical Genetics - Sestri Levante - April 1994.

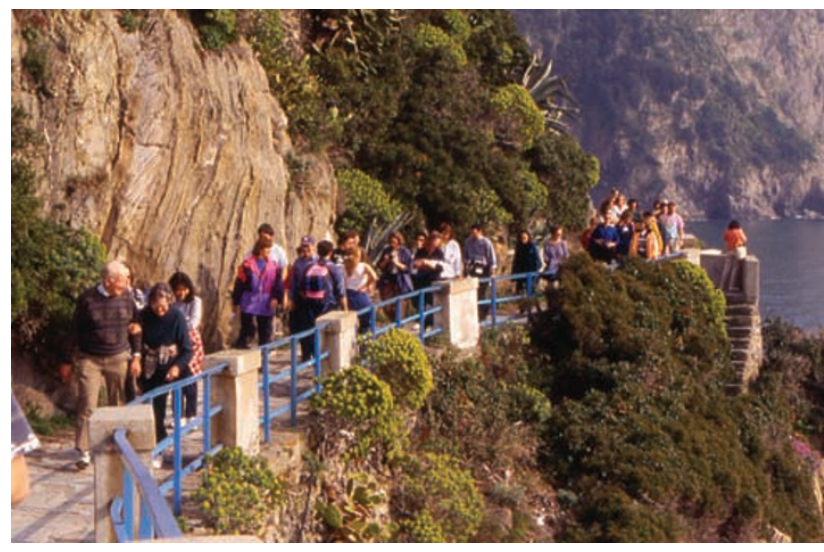

Figure 2 Victor and Anne leading a group of students on the excursion through the Cinque Terre during the 9th course in Medical Genetics - Sestri Levante, April 1996.

dependent on the spirit of peer-control among faculty members. This I believe has been the key of the success of this course, which every year was the 'best ever', as Victor would say as well for the Bar Harbor course. Overall the students have always been extremely good and highly motivated but sometimes too shy to ask questions during plenary sessions. To circumvent this psychological block we invented the 'McKusick's box' where students could drop their questions anonymously (if they wanted to do so) addressed to individual speakers who would answer them at the end of each morning plenary session. Victor was excellent in guiding all the discussions without asking too many questions himself (he would have plenty) but from time to time he could not resist the temptation of dropping his own questions in the 'McKusick's box', as
I could tell from his handwriting... In recent years the use of written questions became a feature of the hybrid courses' of the School, where students from Remote Training Centers can ask questions to speakers by e-mail after following the lectures through live webcasting. Victor would always get excited by the number and quality of questions arriving from Remote Training Centers all over the world. One of the other successful features of the Sestri Levante course was a beautiful excursion through the Cinque Terre where Victor and Anne would often be seen leading a group of students. The course went on in Sestri Levante for 14 years until for logistic reasons it was moved to Bertinoro, next to Bologna, where Victor was the director for the last time in May 2007. A few days later, upon his return to Baltimore, Victor was diagnosed to have cancer. He knew very well what he was facing and he sent to all his friends an e-mail, which started with the following words: 'My renegade chromosomes...'.

I cannot keep myself from mentioning what in my opinion were the most impressive human and professional features of Victor's personality, namely his tolerance, his hard working habits and his great loyalty to Hopkins, an institution of which he was always very proud. In my view his tolerance was the moral counterpart of the intellectual attitude of an 'open mind' which he practiced throughout his life and to which he was probably referring with his usual sense of humour in the conversation with Clair Francomano. I personally know of many instances in which Victor practiced his tolerance by granting his generous support to pupils and professional friends who chose to do things 'their own way'. Victor was a powerful icon in the academia and his tolerance helped many young geneticists to shape their own independent careers 
doing whatever they were most good at. He was himself a 'self-taught' medical geneticist because he switched to genetics when he was already an established cardiologist at Hopkins. The students of the 1989 course in Sestri Levante probably realized the originality of this self-made career when they wrote for the final School party a song in his honour on the tune of Frank Sinatra 'I did it my way' which was an elegant and very funny account of his scientific and personal achievements. Among these the main example and proof of Victor's unique endeavours as a collectionistencyclopaedist is represented by OMIM (Online Mendelian Inheritance in Man). Victor told me once how his habit of collecting clinical observations started when he was a medical student. One of his mentors suggested to him to take note of patients who would get his attention during ward rounds using the small notebooks, which were available for nurses to make note of patients temperatures. Hence the origin of the endless series of notebooks which Victor always carried in his pocket and was always filing in careful chronological order for further consultation at home, where he would start working at 5:00 a.m. each morning to transfer most of his notes into OMIM. It is worth remembering that Darwin was carrying out his field observations in exactly the same way and was using the same type of notebooks. This methodical way of collecting clinical observations must have inspired Victor to build OMIM, the encyclopaedia of genetic knowledge in medicine, which represents today the most consulted genetic database in the world. The parallel between OMIM and the work of the French encyclopaedists of the XVIII century is not out of place because OMIM has become the repository and source of ideas for the most important scientific revolution of our times, that of genetic medicine which will be associated with his name forever.

In spite of his tremendous intellectual achievements Victor kept always the most modest attitude towards science and his colleagues, as documented by the words he borrowed from Isaac Newton for his farewell at the memorial service of first August 2008: 'I do not know what I may appear to the world, but to myself I seem to have been only like a boy playing on the sea-shore, and diverting myself in now and then finding a smoother pebble or a prettier shell than ordinary, while the great ocean of truth lay all undiscovered before me.'

We will miss him. The best way to honour his memory will be to continue at the international level the most significant lifelong mission he accomplished by training several generations of medical geneticists at the Moore Clinic at Hopkins, at the Bar Harbor course and at the European School of Genetic Medicine in Italy.

P.S. Professor Romeo is trying to collect as many pictures as possible from the alumni and faculty of ESGM courses for an album to be presented as a gift to Dr Anne McKusick next year in Bertinoro. If you have attended any of the ESGM courses and if you have pictures in paper or digital copy, he would be grateful if you would please send them to him at the mentioned address.

Giovanni Romeo Department of Medical Genetics, University of Bologna Medical School, Bologna, Italy E-mail: romeo@eurogene.org 